УДК 330.341.1:[005.332.4:664:338.439]

DOI: https://doi.org/10.54929/pmt-issue1-2021-8

\title{
ФІНАНСОВЕ ЗАБЕЗПЕЧЕННЯ ІННОВАЦІЙНОÏ ДІЯЛЬНОСТІ В СИСТЕМІ ПІДВИЩЕННЯ КОНКУРЕНТОСПРОМОЖНОСТІ ПЕРЕРОБНИХ ПІДПРИЄМСТВ АПК
}

\author{
FINANCIAL SUPPORT OF INNOVATIVE ACTIVITY IN THE SYSTEM \\ OF INCREASING THE COMPETITIVENESS OF MANUFACTURING \\ ENTERPRISES OF AGRICULTURAL ENTERPRISES
}

Лагодієнко Н. В. доктор економічних наук, доцент, профресор кафедри обліку та оподаткування, Миколаївський національний аграрний університет ORCID: 0000-0001-9768-5488

Шаповалова І. О. доктор економічних наук, доцент, доцент кафедри економіки та інформаційних технологій Миколаївський міжрегіональний інститут розвитку людини вищого навчального закладу «Відкритий міжнародний університет розвитку людини «Україна»

Рибалко С. В.

доктор економічних наук, доцент кафедри економічної теорії та фрінансово-економічної безпеки, Одеська національна академія харчових технологій ORCID: 0000-0001-5449-4147

Lagodiienko N. V. Doctor of Economics, Associate Professor, Professor of Accounting and Taxation, Mykolayiv National Agrarian University

Shapovalova I. 0.

Doctor of Economics, Associate Professor, Associate Professor of Economics and Information Technology Mykolayiv Interregional Institute of Human Development of the Open International University of Human Development "Ukraine"

Serhiy Rybalko Doctor of Economic Sciences, Associate Professor of Economic Theory and Financial and Economic Security, Odessa National Academy of Food Technologies

У статті охарактеризовано роль інновацій в підвищенні конкурентоспроможності підприємств переробної промисловості АПК в Україні. Визначено, що реалізація ключових напрямів інноваційноїдіяльності підприємств переробної промисловості АПК потребує створення ефективної системи фрінансового забезпечення та залучення значних обсягів фрінансових ресурсів як із внутрішніх, так і зовнішніх джерел. Розглянуто динаміку обсягів та структури фрінансування інноваційної діяльності переробних підприємств АПК. Проаналізовано переваги та обмеження основних джерел фрінансового забезпечення інноваційної діяльності в контексті забезпечення конкурентних переваг підприємств. Обгрунтовано можливості розширення можливостей фрінансування інновацій через активізацію використання нетрадиційних джерел фрінансових ресурсів. 3 метою забезпечення конкурентоспроможності переробних підприємств АПК обгрунтовано необхідність дотримання ними основних принципів формування системи фінансування інноваційноїдіяльності: пріоритетності, плановості, безперервності, множинності, результативності, адаптивностіта цільовоговикористання ресурсів. Ключові слова: інновації, інноваційна діяльність, переробні підприємства АПК, джерела фрінансування, конкурентоспроможність.

В статье охарактеризованы роль инноваций в повышении конкурентоспособности предприятий перерабатывающей промышленности АПК в Украине. Установлено, что реализация ключевых направле- 
ний инновационной деятельности предприятий перерабатывающей промышленности АПК требует создания эффрективной системы финансового обеспечения и привлечения значительных объемов фринансовых ресурсов как из внутренних, так и внешних источников. Рассмотрена динамика объемов и структуры фринансирования инновационной деятельности перерабатывающих предприятий АПК. Проанализированы преимущества и ограничения основных источников финансового обеспечения инновационной деятельности в контексте обеспечения конкурентных преимуществ предприятий. Обоснованы возможности расширения возможностей фринансирования инноваций через активизацию использования нетрадиционных источников финансовых ресурсов. С целью обеспечения конкурентоспособности перерабатывающих предприятий АПК обоснована необходимость соблюдения основных принципов фрормирования системы финансирования инновационной деятельности: приоритетности, плановости, непрерывности, множественности, результативности, адаптивности и целевого использования ресурсов. Ключевые слова: инновации, инновационная деятельность, перерабатывающие предприятия АПК, источники фринансирования, конкурентоспособность.

The competitiveness of business entities is determined by their ability to adhere to an innovative development model, which, based on the use of leading equipment, technologies, products, management decisions, makes it possible to more effectively use the existing competitive potential and take leading positions in the markets. The implementation of the key areas of innovative activity of enterprises of the processing industry of the agro-industrial complex requires the creation of an effective system of financial support and the attraction of significant amounts of financial resources from both internal and external sources. For the theoretical and analytical analysis of the features of the financial support of the innovative activity of the agro-industrial complex processing enterprises, special and general scientific research methods were used: abstract-logical, economic-statistical and comparative analysis, system analysis, methods of logical generalizations, causation. The article describes the role of innovative transformations in increasing the competitiveness of enterprises in the processing industry of the agro-industrial complex of Ukraine. It was revealed that the main source of financing for innovation in the processing industry of the agro-industrial complex is the own funds of enterprises. It has been established that most of the funds are spent on the purchase of ready-made innovative solutions (machinery, equipment and software). The advantages and limitations of the main sources of financial support for innovative activities in the context of ensuring the competitive advantages of enterprises are analyzed. The possibilities of expanding the financing of innovations on the basis of public-private partnerships and the use of non-traditional sources of financing are considered. In order to ensure the competitiveness of the agro-industrial complex processing enterprises, the need for them to comply with the basic principles of the formation of a system for financing innovative activities is substantiated: priority, planning, continuity, multiplicity, effectiveness, adaptability and targeted use of resources. Key words: innovation, innovative activity, agro-industrial complex processing enterprises, sources of financing, competitiveness.

Постановка проблеми. Конкурентоспроможність суб'єктів господарювання визначається їх здатністю максимізувати вигоди від використання наявних ресурсів, водночас мінімізуючи вплив негативних факторів внутрішнього та зовнішнього середовища в умовах їх надзвичайної мінливості та непередбачуваності. Забезпечення таких характеристик діяльності вбачається можливим лише за умови провадження активної інноваційної діяльності, переходу до використання нових прогресивних технологій виробництва продукції, впровадження інноваційних рішень в управлінській сорері, тобто задіяння таких елементів, чинників та механізмів інноваційного характеру, що сприятимуть розвитку конкурентних переваг переробних підприємств.

Необхідність інноваційних перетворень в переробній промисловості обумовлюється тим, що сучасні умови діяльності підприємств галузі характеризуються наявністю низки деструктивних явищ: повільні темпи оновлення основних засобів, висока енерго- та матеріаломісткість виробничих потужностей, недостатній технологічний рівень виробництва. Реалізація ключових напрямів інноваційної діяльності вимагає обґрунтованого створення ефрективної системи фрінансового забезпечення та залучення значних обсягів фінансових ресурсів як з внутрішніх, так і зовнішніх джерел.

Аналіз останніх досліджень і публікацій. В сучасних умовах ефективність суспільного виробництва досягається при зростанні наукового та інноваційного потенціалу, тому проблеми фінансування інноваційного розвитку, зокрема з урахуванням його впливу на забезпечення конкурентоспроможності суб'єктів господарювання, є предметом наукового інтересу значного кола науковців. У працях вітчизняних вчених звертається увага на характеристику форм, методів та тенденцій фрінансування інноваційної діяльності [1-3], узагальнюється досвід прямої та непрямої державної підтримки цього процесу [4-7], розробляються підходи щодо оптимальної моделі фінансового забезпечення інноваційних проєктів на різних етапах життєвого циклу інновацій [8], обґрунтовуються напрями нарощування ефективності інноваційного інвестування [9]. Аналіз закордонних публікацій показує, що іноземні автори зосереджені на розробці інструментів забезпечення прибутковості вкладень в інновації [10], на питаннях формування інноваційних стратегій [11]. 
Тим не менше, в умовах динамічних змін внутрішнього та зовнішнього середовища розкриття специфріки та ролі фрінансового забезпечення інноваційної діяльності в підвищенні конкурентоспроможності переробних підприємств АПК потребує подальшого наукового розгляду, що і визначає мету статті.

Формулювання цілей статті (постановка завдання). Метою статті є дослідження особливостей фрінансового забезпечення інноваційної діяльності в системі підвищення конкурентоспроможності переробних підприємств АПК.

Виклад основного матеріалу дослідження. Конкурентний потенціал підприємств переробної промисловості АПК може перетворитись на стратегічні інноваційні переваги за умови належного рівня фрінансового забезпечення. В $Є С$ на частку промисловості, яка виробляє близько 15\% ВВП, $65 \%$ витрат припадає на НДДКР і майже $50 \%$ витрат - на інновації. Інноваційна активність великих промислових підприємств приблизно вдвічі вища за активність великих підприємств в інших секторах економіки [12]. Звертаючись до вітчизняної практики господарювання, можна констатувати надзвичайно низьку частку високотехнологічної продукції в структурі промислового виробництва, використання застарілої техніки та технологій. Внаслідок зазначених обставин продуктивність праці працівників на підприємствах переробної галузі залишається в 2-3 рази нижчою, ніж у розвинених країнах [13]. Це означає, що внаслідок незадоволеної потреби в оновленні основного капіталу його недостатність компенсується низькопродуктивною працею.

Запорука конкурентоспроможності в сучасних умовах - розвиток на новій техніко-технологічній основі - стримується через обмеженість фінансового забезпечення інноваційної діяльності та відсутність можливостей акумулювати кошти для усунення технологічного відставання підприємств галузі від конкурентів на світовому ринку. Динаміка загального обсягу фрінансування інноваційної діяльності на підприємствах переробної промисловості АПК свідчить про відсутність стійких довгострокових стимулів до її здійснення (рис. 1).

Переважна частина коштів витрачається на придбання готових інноваційних рішень (машин, обладнання та програмного забезпечен-

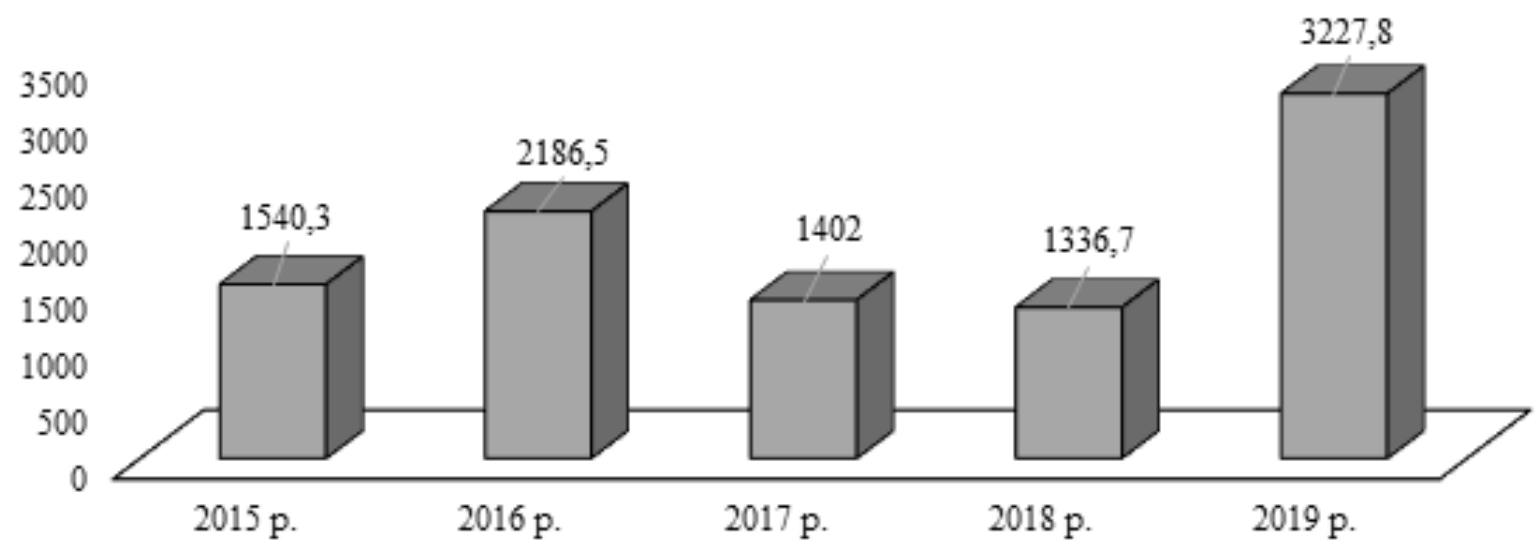

Рис. 1. Загальний обсяг фінансування інноваційної діяльності переробних підприємств АПК, млн грн

Джерело: побудовано автором за даними [14]

ня) - на їх частку у 2019 р. припадало 94,3\% всіх інноваційних витрат переробних підприємств. На внутрішні НДР виділялось лише 0,5\% від усіх вкладень в інноваційну діяльність. В умовах скрутного економічного становища це стало наслідком прагнення забезпечити першочергове фрінансування тих напрямів та продуктів, що дозволяють досягти найшвидшої окупності вкладених в інновації коштів.

Особливості провадження інноваційної діяльності в багатьох випадках визначаються складом та структурою джерел фрінансування інновацій. В нашій країні, згідно зі ст. 18 Закону України «Про інноваційну діяльність», до них належать кошти державного та місцевих бюджетів, власні кошти спеціалізованих державних і комунальних іннова- ційних фрінансово-кредитних установ, власні чи запозичені кошти суб'єктів інноваційної діяльності, кошти (інвестиції) фрізичних і юридичних осіб, інші джерела, не заборонені законодавством України [15]. Найчастіше підприємства прагнуть оптимально поєднати різні форми фрінансування, визначаючи такі склад та структуру джерел залучення коштів для здійснення інноваційної діяльності, які дають змогу утримати власні конкурентні переваги.

Основним джерелом фрінансування інноваційних витрат залишаються власні кошти підприємств - 80-95\% у різні роки (табл. 1), що $є$ характерною особливістю слабких економік та наслідком недосконалості механізмів фрінансування інноваційної діяльності. 
Обсяги і структура джерел фрінансування інноваційної діяльності переробних підприємств АПК*

\begin{tabular}{|c|c|c|c|c|c|c|c|c|c|c|}
\hline \multirow[b]{2}{*}{$\begin{array}{c}\text { Джерела фрінансу- } \\
\text { вання }\end{array}$} & \multicolumn{2}{|c|}{2015 p. } & \multicolumn{2}{|c|}{2016 p. } & \multicolumn{2}{|c|}{2017 p. } & \multicolumn{2}{|c|}{2018 p. } & \multicolumn{2}{|c|}{2019 p. } \\
\hline & $\begin{array}{l}\text { тис. } \\
\text { грн }\end{array}$ & $\%$ & $\begin{array}{l}\text { тис. } \\
\text { грн }\end{array}$ & $\%$ & $\begin{array}{l}\text { тис. } \\
\text { грн }\end{array}$ & $\%$ & $\begin{array}{l}\text { тис. } \\
\text { грн }\end{array}$ & $\%$ & $\begin{array}{l}\text { тис. } \\
\text { грн }\end{array}$ & $\%$ \\
\hline $\begin{array}{l}\text { Власні } \\
\text { кошти }\end{array}$ & 1476,6 & 95,9 & 1771,4 & 81,0 & 1274,3 & 90,9 & 1202,2 & 89,9 & 2767,6 & 85,7 \\
\hline Кредити & 61,8 & 4,0 & 375,0 & 17,2 & 113,3 & 8,1 & 117,2 & 8,8 & 445,7 & 13,8 \\
\hline Іноземні інвестори & 1,6 & 0,1 & 6,5 & 0,3 & - & - & - & - & - & - \\
\hline $\begin{array}{c}\text { Вітчизняні інвес- } \\
\text { тори }\end{array}$ & - & - & 2,1 & 0,1 & - & - & K & \multirow{4}{*}{1,3} & - & - \\
\hline Державний бюджет & 0,005 & 0,0 & - & - & - & - & K & & - & - \\
\hline Місцеві бюджети & 0,3 & 0,0 & 6,5 & 0,3 & $K^{* *}$ & \multirow{2}{*}{1,0} & K & & - & - \\
\hline Інші & - & - & 25,0 & 1,1 & K & & $\kappa$ & & K & 0,5 \\
\hline Всього & 1540,3 & 100,0 & 2186,5 & 100,0 & 1402,0 & 100,0 & 1336,7 & 100,0 & 3227,8 & 100,0 \\
\hline
\end{tabular}

*Джерело: розрахунки автора за даними [14]

** Дані не оприлюднюються з метою забезпечення виконання вимог Закону України «Про державну статистику» щодо конфріденційності статистичної інформації.

Зважаючи на те, що власні кошти переробних підприємств - це, насамперед, прибуток та амортизаційні відрахування, доцільно звернутись до даних, що демонструють фрінансові результати їх діяльності. Впродовж останніх п'яти років частка підприємств промисловості, що отримали прибуток, становила близько $72 \%$ [16]. Це означає, що понад чверть суб'єктів господарювання в галузі мали обмежені можливості щодо використання прибутку для фрінансування інновацій. Крім того, недосконалість механізму інвестиційного використання амортизаційних коштів не сприяє зацікавленості в цільовому використанні цього фрінансового ресурсу для вкладень в розвиток інноваційної діяльності.

В умовах дефіциту власних коштів для розробки та впровадження інновацій джерелом для акумуляції коштів стають кредитні кошти. Залежно від того, хто виступає кредитором, кредити на фрінансування інноваційних проєктів слід виокремити у такі види: державний кредит; банківський кредит; комерційний кредит та іноземний кредит. Однак слід зауважити, що кредитні установи, надаючи позики на реалізацію інноваційних проєктів, з одного боку, надають перевагу тим із них, які передбачають мінімальні ризики, що не характерно для діяльності у сфері інновацій, з іншого - вимагають надання гарантій, що обмежує можливості використання такого ресурсу. Внаслідок цього в структурі фрінансування інноваційної активності переробних підприємств частка інвестиційна кредитних коштів становить лише близько $10 \%$.

Поліпшенню конкурентних позицій переробних підприємств могло б сприяти залучення коштів іноземних інвесторів, зокрема бізнес-партнерів, що зацікавлені у технологічному оновленні виробництва, зокрема це можна реалізувати через створення спільних підприємств та підприємств з іно- земними інвестиціями. Наразі, як свідчать дані офріційної статистики (див. табл. 1), інвестиційні вкладення в інноваційний розвиток підприємств переробної галузі АПК мізерні або взагалі відсутні. Перешкодою для налагодження фрінансування інноваційних проєктів в переробній промисловості за рахунок коштів іноземних інвесторів $€$ низький рівень інтеграції інноваційно активних суб'єктів господарювання до глобального простору, про що свідчить незначна частка підприємств галузі, залучених до інноваційного співробітництва з іноземними партнерами. Лише $11,6 \%$ інноваційно активних підприємств переробної промисловості здійснювали співпрацю з іноземними партнерами у країнах Європи; 6,9\% - з партнерами в інших країнах світу (рис. 2).

Оскільки інноваційна діяльність зазвичай не входить до сфрери інтересів ринку через такі особливості, як висока ризиковість інноваційних проєктів, значний часовий лаг між витратами на виконання робіт та доходами, що отримуються в результаті комерціалізації інновацій, високий рівень невизначеності та відсутність гарантій визнання інноваційної продукції споживачами, сприяння інноваційному розвитку переробних підприємств стає предметом уваги з боку держави. Подолання цього «фріаско ринку» може здійснюватися через пряму участь держави в створенні інновацій через організацію діяльності науководослідних установ, які утримуються за рахунок бюджетних коштів. У сфрері наукового забезпечення технічного і технологічного прогресу переробної промисловості АПК України провідною організацією $є$ Інститут продовольчих ресурсів Національної академії аграрних наук України (ІПР НААН). Діяльність цієї наукової установи полягає у проведенні досліджень, здійсненні і впровадженні наукових розробок у виробництво з метою раціонального 


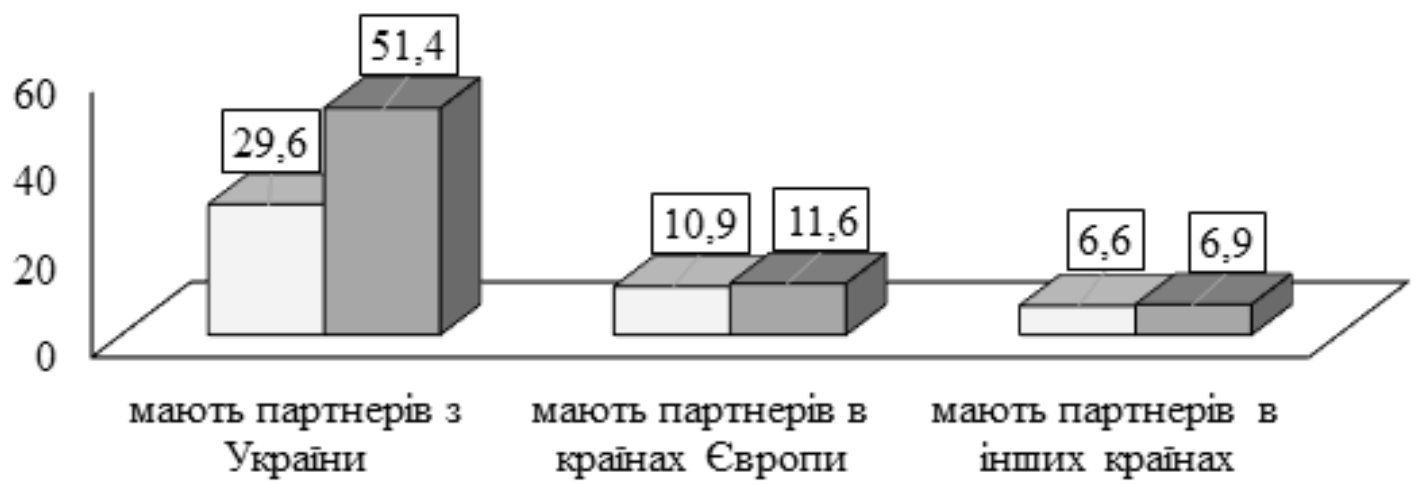

$\square 2014-2016$ pp. $\quad \square 207-2019$ pp.

Рис. 2. Частка кількості інноваційно активних підприємств переробної промисловості, залучених до інноваційного співробітництва, за місцем розташування партнерів, \%

Джерело: побудовано автором за даними [14]

використання сировинних ресурсів, підвищення ефективності виробництва, забезпечення належної якості та посилення конкурентоспроможності вітчизняної продукції у м'ясо- і молокопереробній, цукровій, спиртовій, хлібобулочній, кондитерській, інших підгалузях переробної промисловості України. Основними напрямами діяльності ІПР НАAН є розроблення й удосконалення технологій та устаткування для виробництва м'ясної і молочної продукції, зокрема для дитячого харчування; технологій дієтичних добавок та бактеріальних препаратів для виробництва харчових продуктів; селекція нових штамів промислово цінних мікроорганізмів для застосування у біотехнологіях виробництва м'ясних і молочних продуктів; розроблення сучасного технологічного обладнання переробних підприємств; дослідження хімічного складу і властивостей рослинницької та тваринницької сировини; інноваційних технологій виробництва високоякісних харчових продуктів; технологій застосування нетрадиційної сировини для створення харчових продуктів оздоровчої та профрілактичної дії; нових методів досліджень сільськогосподарської сировини і харчових продуктів; удосконалення контролю якості харчової продукції; розв'язання економічних проблем переробної галузі та продовольчих ресурсів [17].

Враховуючи те, що нововведення набувають в сучасних умовах характеру чинника конкурентоспроможності, участь держави у фінансуванні інноваційної діяльності в переробній промисловості може реалізуватись і через надання субсидій та грантів на проведення фрундаментальних наукових досліджень ученим, які працюють поза межами державних науково-дослідних організацій, а також податкових, митних, амортизаційних пільг або субсидій приватному бізнесу, який вкладає власні фрінансові кошти в проведення НДДКР й інноваційної діяльності $[9,18]$.

Надзвичайно низька частка державного та міс- цевих бюджетів у прямому фінансуванні розробки та впровадження інновацій в переробній промисловості АПК свідчить про відсутність партнерства держави та бізнесу в інноваційному процесі, що спричинює низьку його ефективність та відображається на формуванні конкурентних переваг підприємств галузі. В таких умовах доцільно використовувати модель змішаного фінансування, залучаючи фрінансові ресурси держави, бізнесу, а також кошти з нетрадиційних джерел, таких як венчурні фонди, бізнес-янголи, краудфандинг.

Венчурні фонди виступають посередниками між інвесторами та компаніями, що потребують вкладень для досліджень, освоєння і комерціалізації нововведень. Особливостями таких фондів $€$ : довгостроковість та ризикованість; кошти часто надаються під перспективну ідею без гарантованого забезпечення майном, заощадженнями чи іншими активами; термін інвестицій 3-7 років; ухваленню рішення про венчурне фрінансування передує велика робота з вивчення ризиків та можливостей їх зменшення; венчурні інвестори надають перевагу реінвестуванню; їх прибуток виникає через 5-7 років після продажу пакету акцій за ціною, що в декілька разів перевищує первинне вкладення [19]. За даними Української асоціації інвестиційного бізнесу за 4 квартал 2020 року, в Україні нараховується 1325 венчурних фондів, вартість чистих активів яких становить 294,4 млрд. грн. Однак активність їх співпраці з підприємствами переробної галузі залишається низькою, оскільки, як відзначають аналітики, створення таких фрондів в Україні пов'язане більшою мірою зі спрощеною звітністю й пільгами в оподаткуванні, ніж з фрінансуванням інновацій.

У випадку, коли немає можливості отримати фрінансування від банківських установ та венчурних фондів, альтернативним варіантом виступають кошти бізнес-янголів. Бізнес-янголи - це приватні інвестори, які вкладають фрінансові ресурси в ін- 
новаційні проєкти на початкових етапах діяльності підприємства в обмін на повернення вкладень та отримання частки в капіталі, а також забезпечують власною мережею контактів та досвідом. Такі вкладення становлять незначну частину капіталу інвестора і здійснюються з мотивів очікування зростання вартості вкладеного капіталу та отримання можливості управління підприємствомпартнером. Бізнес-янголи приймають рішення про інвестування в інноваційні проєкти оперативніше, ніж венчурні фонди, що робить такий спосіб фоінансування більш гнучким і динамічним.

Краудфандинг передбачає співпрацю людей, які об'єднують гроші чи інші ресурси для підтримки інноваційних ідей або організацій. Взаємодія між ними найчастіше відбувається в мережі Інтернет на спеціалізованих майданчиках або в соціальних мережах. Краудфандинг є одним з альтернативних способів залучення інвестицій в інноваційні проєк- ти та модернізацію технологічної бази переробних підприємств АПК, причому позитивним «побічним» ефектом такого способу фінансування $€$ можливість поширити інформацію про підприємство та його продукцію серед потенційних партнерів та споживачів.

Фінансове забезпечення інноваційної діяльності переробних підприємств АПК як інструмент підвищення їхньої конкурентоспроможності має передбачати формування цілісної системи, яка передбачатиме залучення коштів з різноманітних джерел та ефрективне їх використання. При цьому обов'язково слід зважувати всі переваги та обмеження джерел, способів та методів фінансування інновацій (табл. 2), що дозволить диверсифікувати ризики та забезпечити необхідні умови для акумулювання фінансових ресурсів та концентрації їх на основних напрямах інноваційної діяльності.

Таблиця 2

\section{Переваги та обмеження джерел фрінансування інноваційної діяльності переробних підприємствами АПК}

\begin{tabular}{|c|c|c|}
\hline Джерело & Переваги & Обмеження \\
\hline $\begin{array}{l}\text { Власні кошти } \\
\text { підприємств }\end{array}$ & $\begin{array}{c}\text { Отримання підприємством повних прав на прибуток, } \\
\text { який очікується за результатами реалізації іннова- } \\
\text { ційних проєктів; уникнення довгострокових кредитів і } \\
\text { нестійкого фінансового стану }\end{array}$ & $\begin{array}{c}\text { Необхідність у довгостро-ко- } \\
\text { вому залученні власного } \\
\text { оборотного капіталу з наявніс- } \\
\text { тю ризиків під час реалізації } \\
\text { інноваційних проєктів }\end{array}$ \\
\hline $\begin{array}{c}\text { Державне фінан- } \\
\text { су- } \\
\text { вання }\end{array}$ & $\begin{array}{c}\text { Низькі ставки залучення ресурсів; можливість } \\
\text { інвестування на довго-строковій основі; розвиток } \\
\text { інноваційної активності переробних підприємств; } \\
\text { створення сприятливих умов для прямих іноземних } \\
\text { інвестицій; створення привабливого інвестиційного } \\
\text { клімату через підвищення лояльності влади }\end{array}$ & $\begin{array}{c}\text { Ризик припинення фінансу- } \\
\text { вання через недостатність } \\
\text { коштів бюджету }\end{array}$ \\
\hline $\begin{array}{c}\text { Кошти кредитних } \\
\text { установ }\end{array}$ & $\begin{array}{c}\text { Незалежність у використанні коштів; можливість } \\
\text { отримання значного обсягу коштів }\end{array}$ & $\begin{array}{c}\text { Ризик втрат через неплато- } \\
\text { спроможність; складність } \\
\text { отримання інноваційних кре- } \\
\text { дитів; високі відсоткові ставки; } \\
\text { обмежений обсяг довгостроко- } \\
\text { вих ресурсів }\end{array}$ \\
\hline $\begin{array}{l}\text { Кошти іноземних } \\
\text { інвесторів }\end{array}$ & $\begin{array}{c}\text { Можливість модернізації технологічних процесів та } \\
\text { виготовленню конкурентоспроможної продукції без } \\
\text { нарощування боргових зобов'язань; підвищення } \\
\text { ступеня адаптації суб'єктів господарювання до умов } \\
\text { конкурентного середовища; використання зару- } \\
\text { біжного організаційного й управлінського досвіду з } \\
\text { впровадження інновацій; збільшення можливостей } \\
\text { експорту інноваційної продукції }\end{array}$ & $\begin{array}{c}\text { Відтік частини прибутків за } \\
\text { кордон; низька привабли- } \\
\text { вість українських переробних } \\
\text { підприємств для іноземних } \\
\text { інвесторів }\end{array}$ \\
\hline Венчурні фонди & $\begin{array}{c}\text { Спрямованість на найбільш ризиковані проєкти; під- } \\
\text { вищення конкурентоспроможності продукції. }\end{array}$ & $\begin{array}{c}\text { Можливість втрати підприєм- } \\
\text { ством контролю на власним } \\
\text { проєктом }\end{array}$ \\
\hline $\begin{array}{l}\text { Бізнес- } \\
\text { янголи }\end{array}$ & $\begin{array}{c}\text { Можливість отримати фінансування на початкових } \\
\text { етапах інноваційної діяльності; оперативність при- } \\
\text { йняття рішень про вкладення }\end{array}$ & $\begin{array}{c}\text { Невеликий обсяг угод; необ- } \\
\text { хідність надавати частку в } \\
\text { капіталі }\end{array}$ \\
\hline Краудфандинг & $\begin{array}{c}\text { Вища прозорість та легкість отримання коштів; } \\
\text { нижча вартість капіталу; чітко визначені часові рам- } \\
\text { ки збору коштів; можливість прорекламувати нові } \\
\text { послуги, продукти і технології }\end{array}$ & $\begin{array}{c}\text { Обмежене коло учасників; } \\
\text { недостатній рівень розвитку } \\
\text { краудфандингових відносин; } \\
\text { невелика поширеність серед } \\
\text { вітчизняних інвесторів }\end{array}$ \\
\hline
\end{tabular}

Джерело: розроблено автором 
Вирішення завдання формування системи фрінансування інноваційної діяльності знаходить відображення у зростанні прибутку від впровадження новітньої техніки та технологій виробництва продукції переробних підприємств АПК, зростанні їхньої конкурентоспроможності та за- воюванні нових ринків збуту. Для досягнення цієї мети забезпечення оптимального співвідношення джерел фінансування інноваційного розвитку має відбуватись з врахуванням основних принципів (рис. 3).

Принципи формування системи фінансового забезпечення інноваційної діяльності переробних підприємств АПК

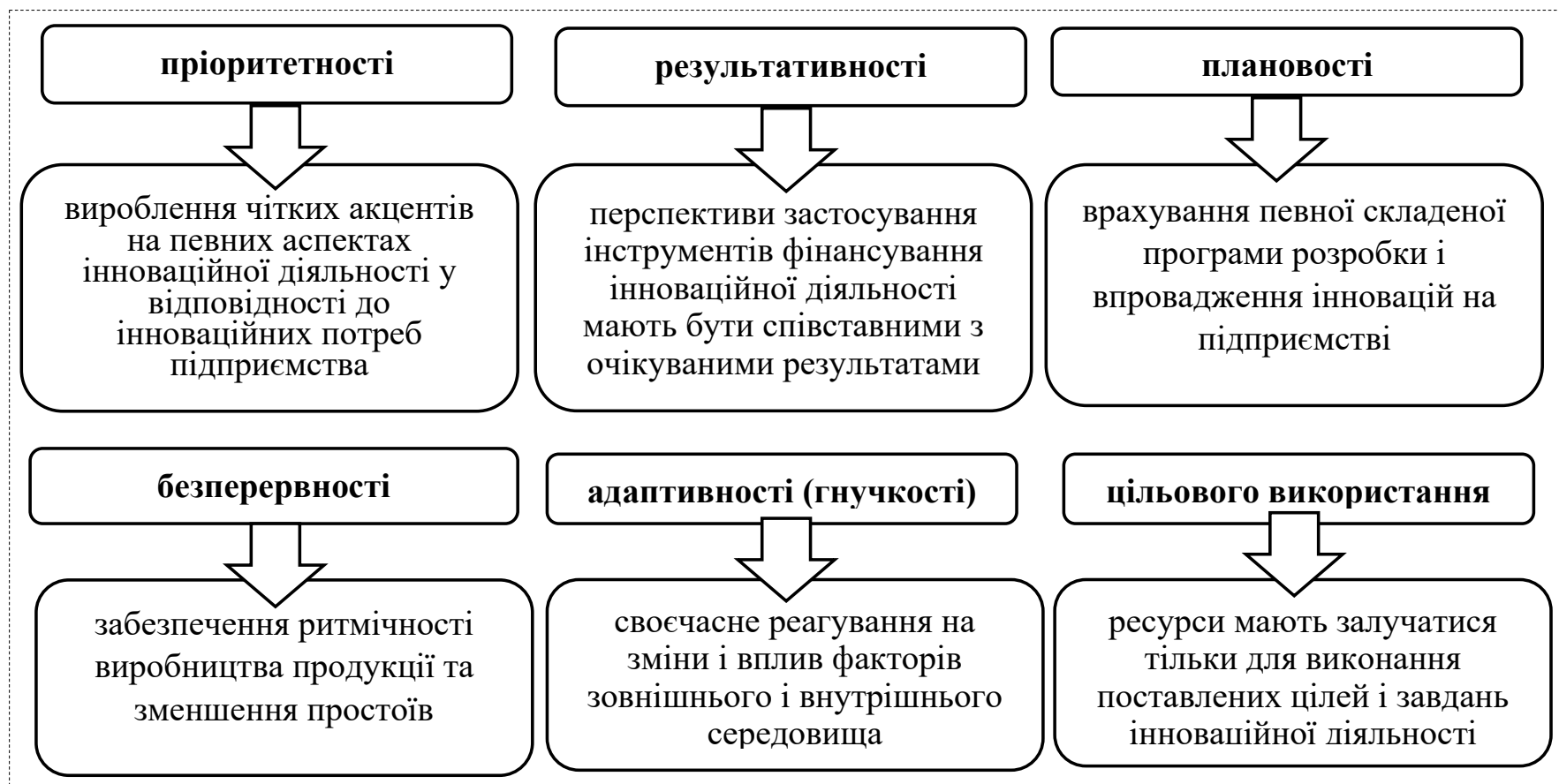

множинності джерел фінансування

комплексне використання зовнішніх та внутрішніх джерел фінансування 3 метою досягнення максимальної ефективності впливу на інноваційні процеси

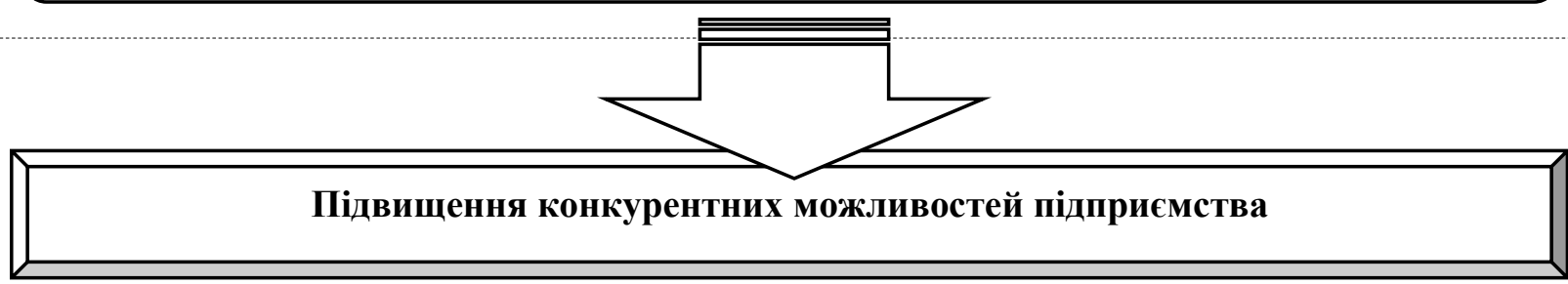

Рис. 3. Основні принципи фрормування системи фінансового забезпечення інноваційної діяльності переробних підприємств в контексті забезпечення їхньої конкурентоспроможності

Джерело: розроблено автором

Отож, організація фрінансування інноваційної діяльності повинна бути орієнтована на різноманітність джерел фрінансування, гнучкість та динамічність можливостей використання фрінансових ресурсів на всіх етапах життєвого циклу інновацій, спрямована на зростання фрінансової віддачі від інноваційної діяльності. За таких умов переробна промисловість спроможна бути буде стати генератором інноваційного розвитку та забезпечуватиме подолання технологічної відсталості й зростання на цьому ґрунті конкурентоспроможності підпри- ємств галузі.

Висновки 3 цього дослідження і перспективи подальших розвідок у даному напрямку. Забезпечення високого рівня конкурентоспроможності передбачає, що ресурси підприємства мають вищу продуктивність та забезпечують отримання вищого, ніж у конкурентів, прибутку. Основою для досягнення такого статусу виступає інноваційна модель розвитку, яка на основі використання провідних техніки, технологій, продуктів, управлінських рішень дозволяє більш ефективно ви- 
користовувати наявний конкурентний потенціал та займати провідні позиції на ринках. Результати проведеного дослідження засвідчили, що в сучасних економічних умовах основним джерелом фрінансування інноваційної діяльності в переробній промисловості АПК є власні кошти підприємств. Забезпечення умов для акумулювання необхідного обсягу фрінансових ресурсів та концентрації їх на основних напрямах інноваційної діяльності має передбачати розширення спектру можливостей їх залучення, зокрема на основі державноприватного партнерства та використання нетрадиційних джерел фрінансування, дотримуючись при цьому принципів пріоритетності, плановості, безперервності, множинності, результативності, адаптивності та цільового використання ресурсів.

\section{БІБЛІОГРАФІЧНИЙ СПИСОК:}

1. Колодяжна І. В. Джерела фінансування інноваційної діяльності підприємств в Україні. Економіка і суспільство. 2017. Випуск 9. С. 448-453.

2. Левицька С. О., Полюхович М. Д. Джерела фінансування інноваційної діяльності в Україні. Наукові записки Національного університету «Острозька академія». Сер. «Економіка». 2017. № 4 (32). С. 55-58.

3. Халатур С. Методичний інструментарій фінансування інноваційної діяльності в АПК. Світ фрінансів. 2019. № 3. С. 65-75.

4. Державне стимулювання інноваційного розвитку суб'єктів господарювання: методологічні засади, світовий та вітчизняний досвід : монографрія / за заг. ред. канд. екон. наук, доц. Л. С. Захаркіної. Суми : Сумський державний університет, 2019. 200 с.

5. Лагодієнко В.В., Орел В.М. Розвиток інноваційної діяльності підприємств м'ясопереробної галузі. Культура народов Причерноморья. 2014. № 273. С. 223-231.

6. Митяй О.В., Лагодієнко В.В., Сафонов В.В. Конкуренто-спроможність сільськогосподарських підприємств як основний важіль сталого розвитку аграрної сфери. Економічний часопис - XXI. 2015, №155(11-12), С. 59-62.

7. Лагодієнко В.В., Лагодієнко Н.В. Моделювання оцінки інноваційної спроможності промислових підприємств. Збірник наукових праць «Фінансово-кредитна діяльність: проблеми теорії та практики». №1 (28), 2019. С. 280-289.

8. Бадрі Г., Панченко Є., Рудуха Н. Глобальні детермінанти і моделі фінансування інновацій. Міжнародна економічна політика. 2018. № 1. C. 7-31. URL: http://nbuv.gov.ua/UJRN/Mep_2018_1_3

9. Фінансове забезпечення інноваційного розвитку України : монографія / за ред. д.е.н., проф. М. І. Диби і к.е.н., доц. О. М. Юркевич. К. : КНЕУ, 2013. 425 с.

10. Afuan Allan. Innovation Management: Strategies, Implementation and Profits. Second Edition. New York: Oxford University Press, 2003. 390 p.

11. Davila T., Epstein M.J., Shelton R. Making Innovation Work. How to Manage It, Measure It and Profit from It. Filadelfia: Wharton School Publishing, 2006. 320 p.

12. Амоша О.І., Вишневський В.П., Збаражська Л.О. та ін. Промисловість і промислова політика України 2013: актуальні тренди, виклики, можливості: наук.-аналіт. доповідь / за заг. ред. В.П. Вишневського;. Донецьк : НАН України, Інститут економіки промисловості, 2014. 200 с.

13. Губіна В.В. Механізми підвищення конкурентоспроможності підприємств харчової промисловості: монографрія. Харків: Панов, 2015. 204 с.

14. Наукова та інноваційна діяльність України: статистичний збірник / відп. за випуск М.С. Кузнєцова. К. : Державна служба статистики України, 2020. 100 с.

15. Про інноваційну діяльність : Закон України № 40-IV від 04.07.2002. URL : https://zakon.rada.gov.ua/laws/ show $/ 40-15$

16. Діяльність суб'єктів господарювання у 2019 р. : статистичний збірник / за ред. М.С. Кузнєцової. К. : Державна служба статистики України, 2020. 153 с.

17. Сичевський М. П., Куць О. І., Савицький Е. Е., Семенівська О. А.. Діючі об'єкти інтелектуальної власності Інституту продовольчих ресурсів НААН. Київ: Аграрна наука, 2020. 24 с.

18. Варфоломеєва В.О. Фінансування інноваційної діяльності як чинник розвитку малого підприємництва. Вісник Української академії банківської справи. 2006. № 2. С. 113-118.

19. Рижикова Н. І. Особливості державного регулювання інноваційно-орієнтованого інвестиційного бізнесу в Україні. Вісник Харківського національного технічного університету сільського господарства. Вип. 202 «Економічні науки». 2019. С. 73-83.

20. Українська асоціація інвестиційного бізнесу. Квартальні та річні огляди ринку управління активами. URL : https://www.uaib.com.ua/analituaib/publ-ici-quart?date=2020-12-31.

\section{REFERENCES:}

1. Kolodiazhna, I. V. (2017). Dzherela finansuvannia innovatsiinoi diialnosti pidpryiemstv $v$ Ukraini [Sources of financing of innovative activity of enterprises in Ukraine]. Ekonomika i suspilstvo - Economy and society, No. 9, pp. 448-453 (in Ukrainian).

2. Levytska, S. O., Poliukhovych, M. D. (2017). Dzherela finansuvannia innovatsiinoi diialnosti v Ukraini [Sources of funding for innovation in Ukraine]. Naukovi zapysky Natsionalnoho universytetu "Ostrozka akademiia». Ser. «Ekonomika» - Scientific notes of the National University "Ostroh Academy», Economics series. No. 4 (32). pp. 
55-58 (in Ukrainian).

3. Khalatur, S. (2019). Metodychnyi instrumentarii finansuvannia innovatsiinoi diialnosti v APK [Methodical tools for financing innovation in the agro-industrial complex]. Svit finansiv. - The world of finance. No. 3, pp. 65-75 (in Ukrainian).

4. Zakharkina, L. S. (E.d.) (2019). Derzhavne stymuliuvannia innovatsiinoho rozvytku subiektiv hospodariuvannia: metodolohichni zasady, svitovyi ta vitchyznianyi dosvid [State stimulation of innovative development of business entities: methodological principles, world and domestic experience: monograph]. Sumy: Sumy State University, 200 p. (in Ukrainian).

5. Lagodiienko, V.V., Orel, V.M. (2014). Rozvytok innovatsiinoi diialnosti pidpryiemstv miasopererobnoi haluzi [Development of innovative activity of meat processing enterprises]. Kultura narodov Prychernomoria - Culture of the peoples of the Black Sea region. № 273. pp. 223-231. (in Ukrainian).

6. Mityai, O.V., Lagodiienko, V.V., Safonov, V.V. (2015). Konkurento-spromozhnist silskohospodarskykh pidpryiemstv yak osnovnyi vazhil staloho rozvytku ahrarnoi sfery [Competitiveness of agricultural enterprises as the main lever of sustainable development of the agricultural sector]. Ekonomichnyi chasopys - XXI. - Economic Journal - XXI. No.155 (11-12), pp. 59-62.

7. Lagodiienko, V.V., Lagodiienko, N.V. (2019). Modeliuvannia otsinky innovatsiinoi spromozhnosti promyslovykh pidpryiemstv [Modeling of assessment of innovative capacity of industrial enterprises]. Zbirnyk naukovykh prats «Finansovo-kredytna diialnist: problemy teorii ta praktyky» - Collection of scientific works "Financial and credit activities: problems of theory and practice». No.1 (28), pp. 280-289.

8. Badri, H., Panchenko, Ye., \& Rudukha, N. (2018). Hlobalni determinanty i modeli finansuvannia innovatsii [Global determinants and models of innovation financing]. Mizhnarodna ekonomichna polityka - International economic policy, Vol. 1, pp. 7-31. (in Ukrainian). URL: http://nbuv.gov.ua/UJRN/Mep_2018_1_3.

9. Dyba, M.I. \& Yurkevich, O.M. (E.d.) (2013) Finansove zabezpechennia innovatsiinoho rozvytku Ukrainy : monohrafiia [Financial support of innovative development of Ukraine: monograph]. Kyiv: KNEU, 425 p. (in Ukrainian).

10. Afuan, A. (2003). Innovation Management: Strategies, Implementation and Profits. Second Edition. New York: Oxford University Press, 2003. 390 p.

11. Davila, T., Epstein, M.J., and Shelton, R. (2006). Making Innovation Work. How to Manage It, Measure It and Profit from It. Filadelfia: Wharton School Publishing, 2006. 320 p.

12. Vyshnevskyy, V.P. (E.d.) (2014). Promyslovist i promyslova polityka Ukrainy 2013: aktualni trendy, vyklyky, mozhlyvosti: nauk.-analit. dopovid [Industry and industrial policy of Ukraine 2013: current trends, challenges, opportunities: scientific and analytical report]. Donetsk: Donetsk : NAN Ukrainy, Instytut ekonomiky promyslovosti. 200 p. (in Ukrainian).

13. Gubina, V.V. (2015). Mekhanizmy pidvyshchennia konkurentospromozhnosti pidpryiemstv kharchovoi promyslovosti: monohrafiia [Mechanisms for improving the competitiveness of food industry enterprises: monograph]. Kharkiv, Panov. 204 p. (in Ukrainian).

14. Naukova ta innovatsiina diialnist Ukrainy: statystychnyi zbirnyk [Scientific and innovative activity of Ukraine: statistical collection] (2020). Kyiv. : State Statistics Service of Ukraine. 100 p. (in Ukrainian).

15. Pro innovatsiinu diialnist : Zakon Ukrainy [On innovation: Law of Ukraine] no. 40-IV, 04.07.2002. (in Ukrainian). URL: https://zakon.rada.gov.ua/laws/show/40-15.

16. Kuznetsova, M.S. (e.d.). (2020). Diialnist sub'iektiv hospodariuvannia u 2019 r. : statystychnyi zbirnyk [Activities of business entities in 2019: statistical collection]. Kyiv. : State Statistics Service of Ukraine, 153 p. (in Ukrainian).

17. Sychevsky, M.P., Kuts, O.I., Savitsky, E.E., and Semenivska, O.A. (2020). Diiuchi obiekty intelektualnoi vlasnosti Instytutu prodovolchykh resursiv NAAN [Existing intellectual property objects of Institute of Food Resources of the NAAS]. Kyiv: Agrarian Science. 24 p. (in Ukrainian).

18. Varfolomeeva, V.O. (2006). Finansuvannia innovatsiinoi diialnostiyakchynnyk rozvytku maloho pidpryiemnytstva [Financing of innovation as a factor in the development of small business]. Visnyk Ukrainskoi akademii bankivskoi spravy - Bulletin of the Ukrainian Academy of Banking. No. 2, pp. 113-118 (in Ukrainian).

19. Ryzhikova, N.I. (2019). Osoblyvosti derzhavnoho rehuliuvannia innovatsiino-oriientovanoho investytsiinoho biznesu v Ukraini [Features of state regulation of innovation-oriented investment business in Ukraine]. Visnyk Kharkivskoho natsionalnoho tekhnichnoho universytetu silskoho hospodarstva - Bulletin of Kharkiv National Technical University of Agriculture, Vol. 202 «Economic Sciences». pp. 73-83 (in Ukrainian).

20. Ukrainska asotsiatsiia investytsiinoho biznesu. Kvartalni ta richni ohliady rynku upravlinnia aktyvamy [Ukrainian Association of Investment Business. Quarterly \& Annual Asset Management Industry Reviews]. (in Ukrainian). URL: https://www.uaib.com.ua/analituaib/publ-ici-quart?date=2020-12-31. 